\title{
Methods for Developing Innovative SME Networks
}

\author{
Anne Haugen Gausdal
}

Received: 4 April 2013 / Accepted: 11 October 2013 /

Published online: 1 November 2013

(C) The Author(s) 2013. This article is published with open access at Springerlink.com

\begin{abstract}
The purpose of this paper is to study whether and how to facilitate the creation of new networks and discuss methods for developing innovative small- and medium-sized enterprise (SME) networks, or more specifically methods that initiate knowledge mobility and support the development of trustful relationships. Network individual, group, and plenary reflection (IGP), a hybrid dialog method, is developed and utilised to this aim. To answer the research question 'In what way is Network IGP a method for developing innovative SME networks?', a case study with longitudinal - mostly qualitative - data and direct participation is conducted in a network of water cleansing SMEs from 2007 to 2013. The answer to the research question is that Network IGP is a method that can be facilitated from the outside to build trustful relationships and initiate mobility of tacit knowledge, especially during the emergence stage, of innovative SME networks. The paper also demonstrates that it is possible to support the emergence and development of SME networks from the outside, building on the participants' knowledge and history. The paper has theoretical, methodological, and practical implications.
\end{abstract}

Keywords SME networks · Methods · Network development · Innovative networks · Network IGP

\section{Introduction}

Firms are increasingly using networks and other partnering arrangements to accomplish their innovative goals (Gassmann et al. 2010). Networks have been on the socio-scientific research agenda for a long time, and the lion's share of this research has focused on questions such as why networks exist, how they emerge, and what characterises successful innovative networks. Small- and medium-sized enterprise (SME) networks have typically been conceived as the result of unanticipated and unplanned coordination between firms with complementary resources and mutual objectives. As Porter (1990, p. 151) puts it:

Electronic supplementary material The online version of this article (doi:10.1007/s13132-013-0169-0) contains supplementary material, which is available to authorized users.

A. H. Gausdal $(\bowtie)$

Department of Maritime Technology and Innovation, Vestfold University College, TØnsberg, Norway

e-mail: ang@hive.no 
'Interconnections (...) often unanticipated, lead to entirely new opportunities. People and ideas combine in new ways'. Another debate in the network literature revolves around the question of whether networks might be developed through planned intervention from the outside or not. Several scholars (e.g. Swan et al. 2002; Wenger et al. 2002) argue that network systems cannot be created directly from the outside, but that it is possible to support their emergence and development. However, 'The idea of directly creating institutional structures or innovation-inducing networks without taking historically formed specific conditions into account, may be an important reason for the failure of many attempts to deliberately create regional innovation systems' (Miettinen 2002, p. 97). Moreover, insideout development seems to be important to achieve organic growth and internal legitimacy in networks (Human and Provan 2000). Hence, it is a challenge to identify relationshipbuilding methods that can be facilitated from the outside in utilising the participant's historical knowledge and building the network from the inside. A network is not a static phenomenon and its development may undergo different stages. A network's lifecycle consists, according to Menzel and Fornahl (2009), of the four stages of emergence, growth, sustainment, and decline.

Since the mid-1990s, a few action research projects have been conducted with the purpose of facilitating the development of learning-oriented networks by using dialogbased methods (e.g. Ennals and Gustavsen 1999; Gausdal 2008; Qvale 2008). These methods are developed as hybrid forms of the original search and dialog conferences (Emery and Emery 1974; Gustavsen 1992). Although these studies have offered valuable knowledge about researcher-facilitated network development, they constitute a small amount of studies. As pointed out above, the overwhelming majority of studies on networks direct primary attention to the properties of existing SME networks, disregarding the question of whether and how to facilitate the creation of new ones. Moreover, there is a need for more longitudinal, qualitative, process-oriented, and outcome-oriented research on networks (Hoang and Antoncic 2003). This paper aims to fill these gaps by asking the following research question: In what way is Network IGP a method for developing innovative SME networks?

To answer this question, a longitudinal action-oriented research project to develop a network of water cleansing SMEs has been conducted. The network, CWN (Clean Water Norway), was initiated in 2007. During the emergence stage, especially, Network IGP interventions have been used systematically to build the network from the inside, to build trust-based relationships and to facilitate learning processes between the firms. In the spring of 2013, CWN can be characterised as an innovative network with three active teams, joint technological development projects and increasing interaction and collaboration among its members.

The paper is organised according to the following structure: First, a conceptualising of the problem and a presentation of the selected case. Second, a discussion of the selection of methods for developing the network and a description of Network IGP. Third, the research methods, the findings, and finally, the discussion and the concluding remarks.

\section{Conceptualising the Problem}

The purpose of SME networks is to increase the firms' competitiveness and innovativeness through collaboration with other firms and intermediaries (Pittaway 
et al. 2004). Specifically, the benefits of networking are 'risk-sharing, obtaining access to new markets and technologies; speeding products to market; pooling complementary skills; safeguarding property rights when complete contacts are not possible; and acting as a key vehicle for obtaining access to external knowledge' (Pittaway et al. 2004, p. 137). To be able to gain such benefits, knowledge mobility is essential. Knowledge mobility means that knowledge needs to be shared, acquired, and deployed within the network (Dhanaraj and Pharkhe 2006). Achieving this is a complex, demanding and fragile process. Many firms fail to establish useful collaborations with other firms, and several networks end up as costly failures (Nooteboom 2002; Pittaway et al. 2004). Important reasons behind this seem to be outside-in development (Miettinen 2002), lack of internal legitimacy (Human and Provan 2000), and lack of trustful relationships (Das and Teng 1998; Nooteboom 2002). Trustful relationships represent a crucial condition and prerequisite for knowledge mobility. In addition, the process of knowledge mobility needs to be facilitated. To build such trustful relationships and initiate knowledge mobility is especially important during the first emergence stage of a networks' lifecycle. The research problem is therefore how to support organic development of network relationships from the inside with a sufficient level of trust, and to initiate knowledge mobility, especially during the important emergence stage of the network's lifecycle.

To make the problem even more complex, knowledge, the essential asset in this debate, has various characteristics, representing different challenges to knowledge mobility. There are many ways to typologise knowledge. Some of them are: Tacit and explicit or codified (Nonaka 1994; Polanyi 1966); Know-what, know-why, knowhow, and know-who knowledge (Lundvall and Johnson 1994). Explicit or codified knowledge is transferable in a formal, systematic language, it is context-independent and can be articulated (Nonaka 1994), captured and stored in writing or in other graphic or symbolic forms. Codified knowledge can be easily transferred from one person and context to another person and context. Tacit knowledge (Polanyi 1966) is hard to formalise, highly personal, experienced, and context-dependent, it is often taken for granted, and hard to share without social interaction (Nonaka 1994). Knowwhat refers to knowledge about facts, and is close to what is normally called information. Know-why refers to knowledge about principles and laws of motion in nature, in the human mind and in society, and has been extremely important for technological development. Know-how refers to skills or capability to do something, e.g. managerial, scientific, and practical work. Know-who involves information about who knows what and who knows what to do. It involves especially the social capability to establish relationships to specialised groups to attend their expertise. Know-how and know-who knowledge is not easy to codify or transmit, and is 'primarily rooted in practical experience and in social interacting' (Lundvall and Johnson 1994, p. 6).

Explicit and scientific know-what and know-why knowledge is usually available on the internet, in books, reports, and journals and is communicated through teaching, speeches, and meetings. Given its codifying and transferrable features, initiating mobility of explicit knowledge is relatively easy, and not trust-dependent. By contrast, initiating mobility of tacit knowledge is more difficult because of its tacit and informal features. To understand, use, or implement explicit knowledge, you may, however, need some tacit knowledge in the form of prior skills or competences 
(Jensen et al. 2007). 'This implies that codified knowledge that stands alone is not economically useful' (Jensen et al. 2007, p. 681). The most important knowledge is therefore often in the complementarity between tacit and explicit knowledge (Nonaka and Takeuchi 1995). Social interaction, collaboration, and trust are necessary preconditions to externalising and sharing tacit knowledge. The most important challenge, and consequently the focus in this paper, is how to initiate knowledge mobility of tacit knowledge.

Trust building in the context of SME networks may be facilitated by the processes of connections, communication, direction, temporary groups, and resource-sharing (Gausdal 2012). To initiate connection and relationships, non-work (Abrams et al. 2003) and low-risk activities (Das and Teng 1998) in small groups (Krogh et al. 2000) seem to be useful. Communication covers both the frequency and quality of communication (Gausdal 2012). Frequent close face-to-face interactions may lead people to care about each other and to better understand each other's expertise (Abrams et al. 2003). Collaborative communication, a combination of active sharing, inquiring, and listening, as in joint problem solving, increases interpersonal trust (Abrams et al. 2003). Shared vision and language give a joint direction that seems to increase trust (Abrams et al. 2003), especially in terms of cognitive trust (McAllister 1995). Swift trust may develop over short, intense periods of interaction in temporary groups (Meyerson et al. 1996). In projects in which each party is dependent on the other to create vulnerability, uncertainty, and risk, 'the trust necessary to act in the face of vulnerability will be there quickly' (Meyerson et al. 1996, p. 183). Furthermore, to build swift trust, stable and standardised roles and clearly defined tasks are required (Möllering 2006). Resource-sharing, or social exchange, is distinguished from a strictly economic exchange by its inherent unspecified obligations, as well as by the fact that it both requires and promotes trust (Blau 1986). This happens by sharing expertise and tacit or experimental knowledge, by giving people access to a limited or sensitive resource when appropriate, and by being willing to let others access personal network contacts (Abrams et al. 2003). As social interaction and collaboration, which are necessary for collaborative learning of tacit knowledge, also seem to be included in these five trust building processes, the main problem is to facilitate processes of connections, communication, direction, temporary groups and resource-sharing at the network level. The processes must, furthermore, encourage organic growth and internal legitimacy.

\section{The Case}

The empirical setting of this study is the development of a network of water cleansing firms, CWN, which is located in the Oslofjord region, south of Oslo. At the outset, in the spring of 2007, CWN encompassed about 15 SMEs. Six years later, in 2013, it is an innovative network constituted by 46 active SMEs, all paying their annual membership fee (about 1,000 $€$ a year). It comprises about 2,200 workplaces, has a turnover of about 650 million $€$ and represents the largest concentration of water cleansing industry in Norway. CWN covers the value chain from sub-suppliers to systems suppliers, consultants, competence organisations, and demanding customers. The system supplier firms specialise in water cleansing technologies, covering the 
cycle from wastewater to clean drinking water. The technologies include water filtration membranes, UV radiation, biological water-cleansing processes, and energy-efficient recycling of sludge and industrial wastewater. In 2010, the first $\mathrm{R} \& \mathrm{D}$ projects to utilise nanotechnology were initiated. The customer base comprises public sewer plants, public water purification plants, construction firms, different kinds of industries producing wastewater, shipping firms and relief organisations. There is a significant growth potential in this industry as the global demand for clean water and the need for reuse and energy-efficient water cleansing is rapidly increasing. As all life is dependent on water, and fresh water is a limited resource on the globe, the market is also a lasting one.

CWN is funded by membership fee, VRI, and Arena grants. The membership fee was introduced in 2008 after the first general assembly. The funding from VRI and Arena - national programs offering economic and professional support-started respectively in August 2007 and November 2011. The purpose of VRI is to increase regional innovation by developing and utilising methods to increase interaction and innovation, and to stimulate the use of R\&D. VRI is financed by the Norwegian Research Council (RCN) and by the County. The Arena program supports long-term development of regional industry clusters with the purpose of stimulating increased innovation based on cooperation among firms, R\&D, universities, and public stakeholders. Arena status, which is financed by Innovation Norway, SIVA (The Industrial Development Corporation of Norway) and RCN, represents a quality mark of innovative networks.

In the spring of 2013, the organisational structure of CWN consists of a network manager, a board, three teams, a Website, articles of association, general assemblies, network meetings, professional trips and network-based innovation brokering. The position of network manager, which amounted to 20-30\% occupation in the period from 2007 to 2011, has been increased to $100 \%$ as from November 2011. The board consists of five members - all firm representatives, and two observers - Innovation Norway and VRI representatives. The teams, consisting of five to nine members reporting to the board, are Team Recruitment, Team Innovation, and Team Global Relations. These teams, which have been coordinated by VRI and firm representatives from 2007 to 2011, are since November 2011 all coordinated by firm representatives alone. The Website www.vannklyngen.no has been active since 2007 and the activity is constantly on a slight increase. In 2011, the site had 75 published news and between 1,000 and 1,200 monthly visitors. The articles of association were developed in the spring of 2008, and are regulated at the yearly general assembly. The network started out in 2007 as a regional network in the Vestfold region, $100 \mathrm{~km}$ south-west of Oslo, denoted as 'The Norwegian Water Cluster' (NWC). In 2010, it merged with a more widespread water network, CWN, to 'CWN-NWC', The merger enlarged the catchment area to the whole Oslofjord Region. The merged organisation kept the NWC organisational structure, including the manager. In 2011, the general assembly decided to change the English name to CWN (to avoid confusing the reader, the network is referred to as $\mathrm{CWN}$ throughout this paper) CWN has organised three to five network meetings a year since 2007, with the purpose of conveying information, sharing knowledge, building relationships and creating enthusiasm. From the very start, and currently still, the main challenges for the CWN member firms were lack of competence and need for recruitment, 
too little technological innovation, fierce competition from foreign stakeholders and lack of focus on the demand of water and the water cleansing industry in the political and public national debates.

\section{Selecting Method to Facilitate the Network Development}

Several dialog-based process methods might be used to solve the research problem; search- and dialog conferences have been particularly dominant. Search conferences were developed to promote democratic change processes in organisations and to let members of the organisation discover the same organisational reality, so that they could act jointly on the basis of this discovery (Emery and Emery 1974). A search conference is a participative event where twenty to forty people from an organisation work progressively for two or three days on creating plans and projects, alternating between small-group work sessions and large-group plenary sessions. An important design principle is that each participant is given the opportunity to voice his or her opinion, and to take active part in defining organisational realities and goals. The outcomes range from changes in work organisations, through innovation and new strategies for growth, to inter-firm alliances (Emery 1999). Dialogue conferences were also developed as a practical response to challenges associated with power asymmetries in large organisations, (Gustavsen 1992). Dialogue conferences were developed during the 1980 s to generate more competitive workplaces and to hinder managers from dominating the discussions with employees. Like search conferences, dialog conferences involve techniques for identifying and summoning together organisational stakeholders for conferences. Dialogue conferences present, however, specific design features such as a strictly regulated allocation of speaker time and the rotation of participants in small groups.

The original search and dialog process methods were characterised by a certain degree of 'purism' with a focus purely on democratic dialogs. In recent years, these original methods have been complemented by 'hybrid' methods, building on the dialog and search conferences, and integrating other elements to complement and adjust the processes to the context. Hybrid methods are characterised by a greater degree of differentiation than their original methods, combining dialog processes with other process methods to foster collaboration, collaborative learning, and joint action. For instance, in developing a network of chemical process firms, dialog conferences were combined with panel debates between firm representatives and local politicians, along with video-animations showing a shared vision for the firms (Qvale 2008). In developing a network in the electronics industry, the hybrid method of Network reflection (Gausdal 2008) was developed. Network reflection, which is a system of several interventions, is a pedagogical method for inter-organisational, part-time management education that seems to have a capacity to build relationships, develop business networks into learning networks (Gausdal 2008), and build interpersonal trust (Gausdal 2012). In this paper, reflecting tasks, the method's core activity, are further developed from network reflection as Network IGP, illustrated below. The common denominator of these hybrid methods is that elements from different methodological sources are combined to handle practical challenges associated with developing the networks and the specific context. 
Several dialog process methods may be used to facilitate the inside-out development of SME networks. Each method is developed in a specific historical context as a response to handling specific challenges, and their strengths and weaknesses translate into positive or negative results depending on the specific context in which they are utilised. When selecting among process methods one should therefore focus on the specific challenges at hand and carefully select the methods most appropriate for handling them. First, in SMEs, the firms are small and the managers and employees are generally very busy. They are not able or willing to spend two or three days participating in extensive dialog and search conferences to develop a network that perhaps might be useful in the future. The dialog events must therefore be short and efficient and should not last longer than a half day. Second, when initiating a network, the firm representatives are generally strangers to each other. An important task is therefore to help people connect and build relationships, and to facilitate trust building between them.

CWN holds several particular contextual features that should be properly considered. Most of the firms are nonhierarchical and employ highly educated engineers and researchers who participate actively in developing the firms. The main challenge in these firms is not to create strong collaborative processes between managers and employees, but rather to improve the innovative capacity of the firm and to win larger and more challenging customer projects. Moreover, the technical engineering-dominated culture calls for strictly structured processes. Network IGP was developed to fit such a context and selected to facilitate the development of the CWN network.

\section{The Network IGP Method}

Network IGP is inspired by dialog conferences (Gustavsen 1992), cooperative learning (Johnsen and Johnsen 1994), and reflection (Schön 1983). It is deduced from network reflection (Gausdal 2008) and developed by the author. IGP is an acronym for Individual, group and plenary reflections. Network IGP holds a combination of individual and collective reflection on a given topic, problem or question. Divided into inter-organisational groups of three to six, the participants start out with a short preparing process. This process includes saying what their names are, which firm/organisation they represent, their position in the firm and sharing some safe personal information, for instance how many years they have been working in their firm, where they live, their favourite leisure activity or their plans for the next holidays. The roles of group manager and secretary are then assigned among the group members by using a random technique, for instance the persons that travelled the longest and the shortest way in their last holiday. Then the process continues with individual reflection in a given time, for instance $3 \mathrm{~min}$, on a given topic, problem or question. A collective group reflection ensues, time-controlled, e.g. $30 \mathrm{~min}$. The collective group reflection starts with talking rounds, where the participants share their ideas and suggestions from their individual reflection one by one with limited talking time (e.g. 1-2 min) for each person on each round. During the talking rounds, nobody interrupts each other. The participants are allowed to ask clarifying questions, but not to contradict others. The collective group reflections 
proceed with normal discussion, group reflections, perhaps prioritising of answers, and finally the group's answer to the given topic, problem or question is arrived at. The group is given a definite time to meet in a plenary session for presenting their result. The plenary reflection consists of short presentations, for instance $2 \mathrm{~min}$, of the answers to the given topic, problem or question from each group. These presentations may be followed up by a plenary prioritising and/or discussion.

A Network IGP process may have different length. The choice of length of the total process and of the different phases depends, among other factors, on the aim of the process, the complexity of the topic, problem, or question, the use of technological facilities and the time available. It may last from $10 \mathrm{~min}$ to a whole day. The phases of Network IGP, their content and length are presented in Table 1. For more details about Network IGP, see Appendix 1.

\section{Research Methods}

The research methods are a combination of case study (Eisenhardt 1989; Yin 1984) with longitudinal data (Pettigrew 1990), direct participation, and action research (Reason and Bradbury 2001a). By summarising the empirical richness of a single case, this study provides a first step towards the formulation of a theory. According to Siggelkow (2007, p. 21), 'Inductive research strategy that lets theory emerge from the data can be a valuable starting point'. As a single case provides the opportunity for unusual research access allowing exploration in a specific population (Yin 1984), it also allows the exploration and the detailed description of a phenomenon (Siggelkow 2007). Even if a multiple-case study typically provides a stronger base for theory building (Yin 1984), a single-case study may be a very powerful example providing a more convincing argument about causal forces than broad empirical research (Siggelkow 2007). As Greenwood and Levin (1998) have pointed out, action researchers typically collaborate with members of a community or organisation(s) who are seeking to improve their situation. In this process, they both participate in and write about the actions that are necessary to achieve such improvements. As the author of this paper was the main researcher and facilitated most of the interventions herself, she brought together action and reflection, theory and practice in participation with others. These are, according to Reason and Bradbury (2001a), the very features of action research.

Table 1 The phases and content of Network IGP

\begin{tabular}{llcc}
\hline Phase & Content & Duration & Managed by \\
\hline $\begin{array}{l}\text { Preparing process } \\
\text { Individual } \\
\text { reflection }\end{array}$ & $\begin{array}{c}\text { Presentation of formal and personal information } \\
\text { Individual reflection on a given } \\
\text { topic, problem or question }\end{array}$ & $\begin{array}{c}2-5 \mathrm{~min} \\
1-10 \mathrm{~min}\end{array}$ & $\begin{array}{c}\text { The group manager } \\
\text { The group manager }\end{array}$ \\
$\begin{array}{c}\text { Talking rounds and sharing individual ideas. } \\
\text { Plenary reflection }\end{array}$ & $\begin{array}{c}\text { From } \\
\text { Sharing group answers (plenary discussion) }\end{array}$ & The group manager \\
& She min & The process facilitator
\end{tabular}


This study includes mostly qualitative data from interviews, direct participation, observations, document studies, and interventions, along with some quantitative data from a roster-rating questionnaire (Wasserman and Faust 1994). The empirical part lasted 4 1/2 years - from September 2007 to May 2011 - and consists of $540 \mathrm{~h}$ of field work, 22 telephone interviews, and 9 in-depth interviews with 15 informants. The primary fieldwork method was direct participation (Reason and Bradbury 2001b; Whyte 1991) in the network activities and facilitation, or process management, at network meetings. The goal here was to facilitate dialogs and trust-based relationship-building between people in the network firms during the emergence stage of the network. A number of meetings were organised for the participant firms, the Network IGP method being employed as the main process for most of these meetings from 2007 to 2008 . The author interacted closely with the network manager and the key network participants when planning and executing many of the meetings. The second fieldwork method was employed more indirectly in planning and organising the network formation. This consisted of assisting the firms in setting up articles of association as well as a formal network board, with elected members from the participant firms and other stakeholders. The third fieldwork method consisted of contributions in establishing and coordinating a set of smaller inter-organisational teams with responsibility for practical collaboration on recruitment, marketing, staff development, and R\&D. The fourth and final fieldwork method was the author participating as an elected member of the network board from 2008 to 2011. In addition to the author, three other researchers have been somewhat involved in the fieldwork. Table 2 provides a timeline of the network meetings, the applied method, and the role of the researchers.

The questionnaire informants were the CEOs or middle managers in the firms. Eight of the in-depth interviews were conducted on a stratified sample of key informants - CEOs and middle managers - from 2008 to 2010. The ninth interview was conducted in 2011 as a group interview with seven informants from the network board. Most (seven out of nine) of the in-depth interviews were performed by two researches, and two by one researcher. All the in-depth interviews were recorded and fully transcribed. The collection of data was carried out through informed consent. In reporting the results, informants and firms were made anonymous. The document studies consist of minutes, emails and planning documents from the emergence stage of the network, the VRI application, agenda and minutes from all the board-, network- and team meetings, task-notes from all the Network IGP processes, a CWN report, the Arena application, and the CWN Website (www.vannklynge.no).

Finally, a telephone-based roster rating questionnaire (Wasserman and Faust 1994) was carried out on the CWN participants - with $100 \%$ response rate-in the spring of $2008(N=22)$. The purpose of this questionnaire was to document changes in interaction between the firms during the emergence stage. Interaction was measured by using Hansen (1999) scale for frequency of contact and feeling of closeness, which represents a further development of Granovetter (1973) scale.

Results

Before CWN was established in 2007, there was relatively little interaction between the firms (Gausdal and Hildrum 2012). Some firms knew about each other, some had 


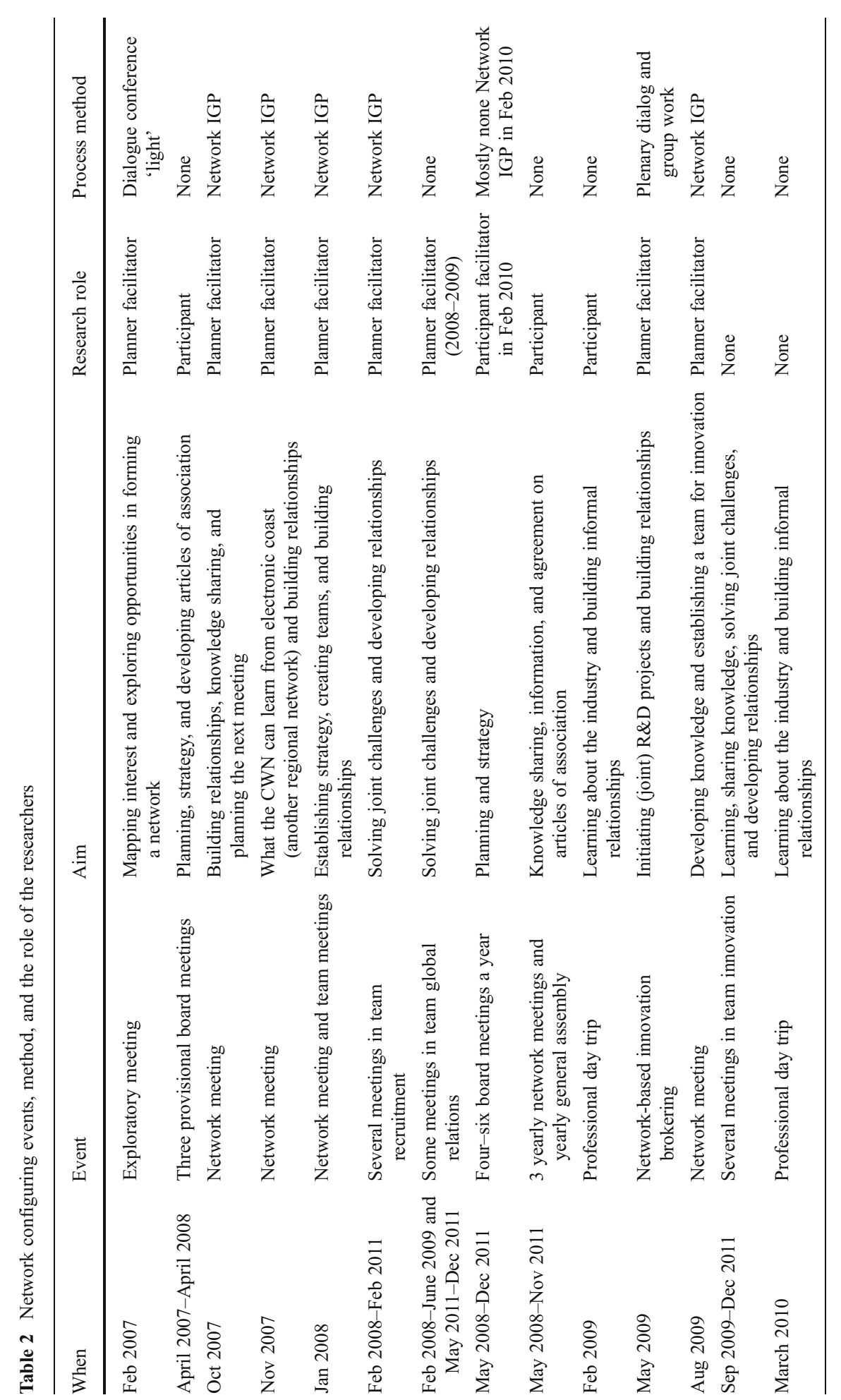




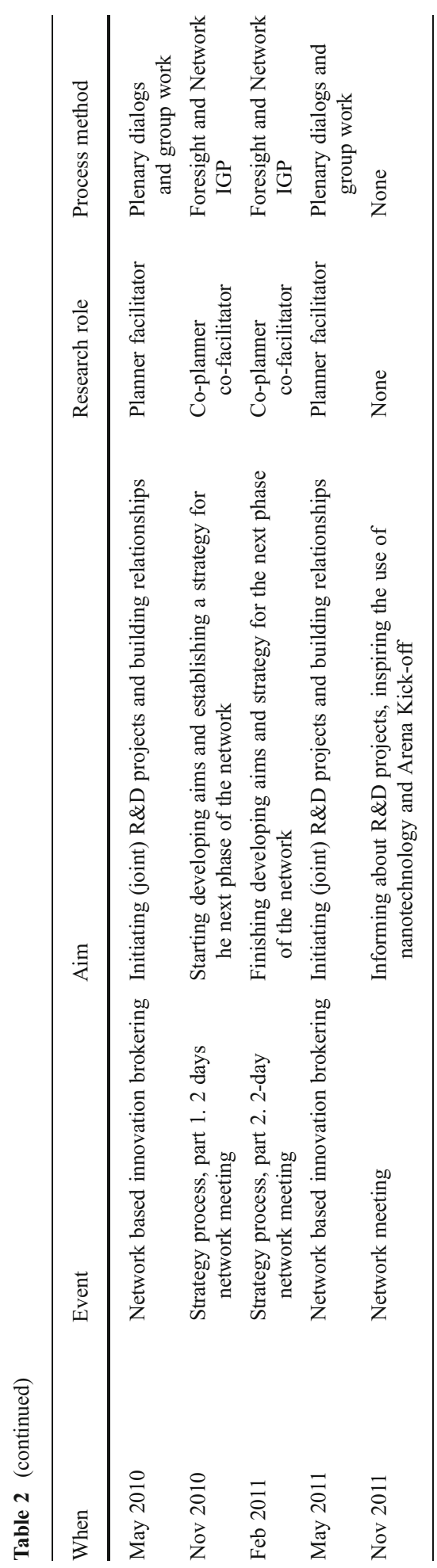


established bilateral relationships, but outside of these there was fairly little contact. The first initiative to establish the network was taken in January 2007 by the directors of a local business development organisation (TU), the regional branch of the National Employers' Association, and researchers from Vestfold University College (VUC). The first step was mapping out potential participant organisations and inviting them to a meeting in order to explore opportunities for creating a new network. The exploratory meeting showed that the participants experienced very similar challenges, and that they did wish to participate in a joint regional network organisation. Therefore, a temporary board was established, a funding application was submitted to the VRI program, and a first Website was launched. To develop the network further, Network IGP was used systematically at several meetings, especially during the emergence stage. Table 2 shows all the network meetings in the period 2007-2011 and their possible applied process methods.

Network IGP was introduced at the first ordinary network meeting in October 2007 to determine what the main topic at the next meeting should be. The 15 participants were given a menu of five topics, e.g. how to motivate your employees, innovation management, and learning from another successful regional network of electronic firms, the Electronic Coast. The participants were asked to reflect individually for $2 \mathrm{~min}$, then discuss with their neighbor for $3 \mathrm{~min}$. In the plenary part, each pair related their chosen topic. All the pairs had elected 'Learning from the Electronic Coast'. Therefore, at the next network meeting three representatives from the Electronic Coast shared their experiences, and gave CWN a lot of advice based on their efforts, gains, pitfalls and successful activities. Successively, the Electronic Coast and the CWN participants worked together in four groups for $40 \mathrm{~min}$, using Network IGP, on how the waterfirms could utilise $\mathrm{CWN}$ in their value creation. One of the conclusions in the plenary session was 'organising network teams ASAP'. At the next network meeting, consequently, potential CWN teams were selected and attempted to become operative. A list of eight possible teams was developed on the basis of suggestions from the 'Electronic Coast' meeting, and important network subjects were derived from a CWN survey. After presenting the list, the researchers asked the 28 participants which team they wished to join. Immediately afterwards, the initial team meetings were organised as a part of the network meeting, applying Network IGP with external trained facilitators. One informant describes this process in the following manner: We were almost forced to sit down in groups and try to get it going, and I think probably it was a precondition. If you did not do it that way, I do not think we had been sitting with the teams today (CEO, System Developer, 2008). It was attempted to start up four teams at the meeting, and three of them became a reality: These were Team Competence, Team Recruitment, and Team Global Relations.

The first ordinary meeting in Team Competence was partly managed as a Network IGP process, in which the participants were given the task of turning their previously expressed aspirations into concrete action plans. The team members were enthusiastic about planning concrete activities, and during the discussion, they developed an action plan for personnel recruitment and competence development. After this meeting, the team members started carrying out practical work, including participating in educational conferences, initiating collaboration with the public labour-market service on recruiting foreign engineers, visiting a university to discuss recruitment and competence development strategies, and organising a 'student night' 
between the network firms and engineering students at VUC. Given a somewhat overlapping aims, Team Recruitment and Team Competence were merged into one single team, Team Recruitment, in late 2008. In between these joint activities, there were team meetings in which the members followed up past activities and discussed future action. Some of the following meetings in team recruitment from 2008 to 2009 were also partly managed as Network IGP processes. Thereafter, no particular process method was used to manage the meetings in this team, except for the first meeting after the merger with several new team members in 2010. The Global Relations team has never been managed by applying Network IGP. In 2009, the activity declined and this team actually came to a full halt until it was restarted in 2011.

Several network activities, like student nights, professional trips, Team Global Relations, and network-based innovation brokering were managed without using Network IGP. Indeed, from March 2008-2009 the network meetings were managed without using any particular method altogether. However, at the network meeting in August 2009, Network IGP was applied as a 50-min process to set up a team for innovation and to discuss how the firms worked with product development. Team Innovation started up as a preliminary project, with a facilitator that applied Network IGP at some of the meetings. The provisional team was consolidated into a proper team one year later; it is still active and has had a waiting list for aspiring participants. Team Competence/Recruitment has been the most active in CWN since the teams were established in January 2008, and it is still active five years later, in 2013.

Usually the board meetings were not managed with the help of any methods, but in February 2010 the board requested the author to facilitate the meeting by using Network IGP. It was not an ordinary board meeting, but a whole-day meeting between the CWN and the NWC boards to discuss a possible merger between the two networks.

To handle the maturity of the network, the merger between $\mathrm{NWC}$ and $\mathrm{CWN}$, and to prepare for the Arena application, in 2010 the network was in need of a new strategy process. Such a process was therefore initiated and completed in the spring of 2011, managed as a light version of Foresight, with Network IGP as the method for all the group work.

Summing up, Network IGP was applied 20 times at network and board meetings, each time lasting from 10 to $75 \mathrm{~min}$. For more detailed information on the number of participants, the duration and the questions at the network meetings using Network IGP, see Appendix 2.

The results of the roster rating questionnaire show a $30.5 \%$ increase in frequency of contact and a $28.9 \%$ increase in the feeling of closeness among the firms from the autumn of 2006 to the spring of 2008 - the emergence stage of the network. As Levin and Cross (2004) also found that the two items 'frequency of contact' and 'feeling of closeness' yielded similar results, this may strengthen the validity of these results. Although $59 \%$ of the firms admitted a lack of personnel in 2008, 18 out of 22 firms showed a positive attitude to share their knowledge with other CWN firms. The first destinations of the yearly professional trips were regional firms and universities, but in 2012, there was joint participation at the international IFAT ENTSORGA conference.

Workshops for network-based innovation brokering for building relationships and initiating (joint) R\&D projects have been organised yearly since 2009 . As a result the 
firms started to cooperate on R\&D projects, and by 2013 eighteen R\&D projects have been initiated by the network: Four in 2009, seven in 2010, four in 2011 and three in 2012. Three of these projects represent cooperation with $R \& D$ competence, radically new to the firms: Nanotechnology and fluid dynamics. A major strategy process to develop CWNs' vision, aims, and strategy for 2012-2015, and to build the foundation and anchoring for the application to the Arena program, was organised in 2010-2011. CWN achieved Arena status ultimo 2011. A good and simple measure of the benefit from the network is the firms' membership and activity. The number of paying firm members has increased by $307 \%$, from 15 in 2008 to 46 in 2013 . The network activity, measured in hours invested by the firms in activities initiated by the network, is quite imposing: 2,596 h in 2009 and 2,350 h in 2010.

\section{Findings}

The research problem is how to support organic development of network relationships from the inside with a sufficient level of trust, and to initiate mobility of tacit knowledge, especially during the emergence stage of network development. Firstly, several findings indicate that the use of Network IGP has contributed to the building of relationships within the network. Some quotations supporting this relationship-building effect are reported below:

During the brainstorming session everyone had to contribute, your turn came and you just had to say something and you were forced to think. It was a good way both to become acquainted with the others and to hear all points of view. You were forced to get started, you had to think and enter the process (Middle Manager, System Developer, 2008).

Working in groups in this way has been smart. The technique is in a way a little naïve, but has large practical consequence. You get acquainted with others and understand what they actually engage in (CEO, System Developer, 2008).

CWN gives us insight in each other's knowledge, sharing of ideas, business cooperation, communication with the regional universities and Innovation Norway, and an informal professional network (CEO, System Developer, 2009).

The fact that the facilitator is thinking 'process' binds us together, and I think that in many ways it constitutes a link among several of these actors. It has been very good (CEO, Demanding Customer, 2011) (Reime 2011, p. 50).

During the strategy process we worked intensively in groups for two days, and I felt that we became a lot more familiar and cohesive with each other [...] It was great (consultant, 2011).

Furthermore, some of the CEOs have started to use Network IGP themselves to build relationships inside their own firms. As one of them reported:

In my firm there are several employees that do not know each other, and we need to let them become acquainted and to build relationships within the 
technical environment ... I think your technique is more useful than what I thought at the start, so now I have planned to copy it (CEO, System Developer, 2008).

These quotations, along with the approximate $30 \%$ increase in frequency of contact and feeling of closeness among earlier strangers, indicate that the knowwho competence is increased and that relationships have indeed been build. The quotations, moreover, indicate that the 'technique' or 'process', which aims at Network IGP, contributed actively in building these relationships.

Secondly, trust seems to have been built among the network participants at an early stage, which is also emphasised by one of the CEOs:

Trust is the keyword. The road to achieving such a high level of trust among us, allowing us to share business ideas and future plans, is long. In CWN we trust that what we tell each other will not be misused. We can therefore utilize each other's competence without negative implications for the firms. This level of trust is the most important result of CWN (RCN 2010, p. 4).

During the emergence stage, from 2007 to 2008, the participants showed a lot of trust-dependent behavior. CEOs and middle managers contributed actively by sharing their knowledge in temporary groups at network meetings, and started to work actively together in network teams. The firms carried out their first joint recruitment campaigns, offered each other to use their laboratory facilities, and started contacting each other to discuss joint customer projects. During the growth stage, from 2009 onwards, they also started sharing R\&D ideas and challenges as well as collaboration in several joint R\&D; for instance, two - partly competitive - firms collaborated with researchers on a R\&D project to use new enabling technology-BioMEMS - to identify and measure water pathogens. Furthermore, the firms collaborated in several joint customer projects, and one firm invited all the other CWN participants to use their newly established Egypt office (www.vannklyngen.no 2009). Therefore, a vast amount of characteristic- and process-based trust seems to have been built in the emergence stage of CWN (Gausdal and Hildrum 2012).

The effect of building relationships and trust is, moreover, acknowledged to be so efficient that the chairman of the board chose Network IGP as the method to manage their important merger meeting between the CWN and the NWC board in 2010.

Furthermore, it appears that using the Network IGP method systematically has built up some kind of institutional trust in the network, as three informants asserted: $I$ think we have found a good method to make team meetings effective. I say 'we' have found, but it is, of course, with good help from you (Middle Manager, System Developer, 2008). My firm would not have continued in the network if you had not managed it so professionally (Middle Manager, System Developer, 2009). I don't think this would have worked out if you had been removed, and the firms had been the only actors. You are the oil in the machinery (Middle Manager, Demanding Customer, 2009).

Social events play a key role in stimulating trusting relations, which are reinforced by performing such events off-site (Krogh 1998). The fact that all the network and team meetings were located to different plants may therefore also have influenced the building of trust. The connection effect of Network IGP is discussed in the 
'Relationship-building' section in the first part of this findings chapter. The trustbuilding process communication consists of collaborative communication and frequent communication, which are both discussed in the 'Relationship-building' section, also above. Direction is about shared vision and language. In this case, at the network level, Network IGP was used to develop a shared direction during the three first network meetings in 2007-2008, as well as during the strategy process in 2010-2011. At the team level, Network IGP was used to plan the team direction and activities in two teams. Hence, it contributed as a method to influence direction, language, and way of working. Because the group processes of Network IGP consist of short intense periods of interaction in temporary groups, swift trust may be developed among the participants. During the group work of Network IGP the participants shared time, ideas, stories, experiences, contacts and tacit and experimental knowledge with each other, which represents different types of resource-sharing. The use of Network IGP seems therefore to encompass all of the five trust-building processes of connections, communication, direction, temporary groups, and resource-sharing (Gausdal 2012), and to have a positive influence on the creation of trust in CWN.

The quotations, processes and facts about the joint activities among earlier strangers, and partly competitors, indicate that different types of trust have indeed been build. The quotations, moreover, indicate that the 'method' or 'management' or 'oil', which aims at Network IGP, may have contributed in building such trust.

Thirdly, and finally, the use of Network IGP appears to have initiated mobility of tacit knowledge in the network. As one informant said:

The method the facilitator uses in order to, in a way, extract ideas from people and let them contribute constructively in a very short-time horizon [Network IGP] is quite an interesting way of bringing out part of what is going on inside different people (Consultant, 2011) (Reime 2011, p. 50).

I argue that this 'bringing out part of what is going on inside different people' is an expression for externalisation of tacit knowledge. Another quotation illustrates the effect of the collaborative communication:

It is about meeting people, for instance by group work. Then you get to know them and you understand what they work with, and I feel we jointly come upon new impulses/ideas. They know something we need, we talk together and the firms are positive to collaboration (Middle Manager, Demanding Customer, 2009).

This quotation points at how the group work in Network IGP contributes to sharing, acquiring, creating, and deploying knowledge between network members, which is in accordance with the definition of knowledge mobility. In addition, parts of the quotations from the relationship-building section, e.g. 'to hear all points of view' and 'understand what they actually engage in' reveals that knowledge mobility is initiated. Other findings that indicate knowledge mobility going on are CEOs and middle managers sharing their knowledge in temporary groups at network meetings, contacting each other to discuss joint customer projects and starting sharing challenges and collaborating in several joint R\&D projects. Moreover, the systematic use of Network IGP in this case resulted in relatively frequent and close interactions at the network and at the team level. Abrams et al. (2003) argue that frequent close 
interactions may lead people to care about each other and to understand each other's expertise better.

These quotations and facts about the joint activities indicate that knowledge mobility has indeed been initiated. The quotations, moreover, indicate that the 'group work' or 'method', which aims at Network IGP, may have contributed in initiating this mobility of tacit knowledge.

\section{Discussion}

The findings chapter shows that Network IGP contributed in building network relationships, trust, and initiating the mobility of tacit knowledge. This chapter starts out discussing how each phase of Network IGP may have influenced these findings.

During the preparing process phase, the participants work face-to-face in interorganisational groups, saying what their names are, which firm/organisation they represent, their position in the firm and sharing some safe personal information. A minimum degree of participation in word-of-mouth trust, which is about reputation and motivates people to connect, is required before people can induce any cooperation (Dellarocas 2003). To initiate relationships in networks it is important to make people connect. Abrams et al. (2003) emphasise the value of face-to-face contact, making interactions meaningful and memorable. To initiate collaboration, low-risk activities are proposed (Das and Teng 1998). Abrams et al. (2003) point out that non-work connections help people to relate to each other on a larger ground than just on an instrumental basis; individuals come across as more 'real' and hence safer, something that reduces vulnerability. Furthermore, Abrams et al. (2003) argue that the discovery of a common background-e.g. education and family status, common values and predispositions - contributes to the building up of such connections. Therefore, the preparation process of Network IGP consists of sharing some personal information, as one of the participants commented: You have to say something personal about yourself' (CEO, System Developer, 2008). In the preparing process phase the participants therefore start developing know-who knowledge about each other and developing word-of-mouth trust.

During the individual reflection phase the participants reflect on a given topic, problem or question. To increase the learning effect 'It is critical that this reflection alone be allowed to happen on the manager's (i.e. participant's) own terms' (Mintzberg 2004, p. 255). Hence the topic, problem, or question they are asked to reflect upon when using network IGP must be developed carefully to match the participants' own context. Therefore, in this case, much effort has been put into the formulation of the topic, problem or question as clearly and appropriately as possible. Individual reflection is an important part of the individual learning circle (Kolb 1984). Reflection is a partly conscious cognitive process about learning from experience (Schön 1983), and an active and purposeful process of exploration and discovery, often leading to unexpected outcomes (Gray 2007). It is, moreover, a way to make tacit knowledge more explicit and shareable. As the participants are practitioners, and their experiences and actions are essential in the interventions, reflection-on-action is very likely to occur. According to Schön (1983, p. 28), when we reflect-on-action we think back to discover how our knowing-in-action may have 
contributed the outcome. I believe the 'externalisation of tacit knowledge' effect of network IGP is partly due to the reflection processes. The individual reflection phase therefore results in individual learning and starts externalising of tacit knowledge.

During the collective group reflection phase, the participants first share their ideas and suggestions from their individual reflection, then they discuss and reflect together and finally arrive at the group's answer to the given topic, problem or question. This method of utilising participants' actual experiences in conjunction with guided reflections and inter-organisational tasks enables the participants to create and share local explicit and externalised tacit knowledge. They also practise collaborative communication. When the participants share their ideas during this phase, they often do this by telling stories from their own experience. Storytelling presents information in a very interesting way which helps people create order out of a chaotic world, and it is an important part of collective learning (Ramsey 2005). According to the performative collective learning circle (Ramsey 2005), one story often inspires another story, and sharing stories enables people to coordinate understanding and meaning, which in turn influences joint action and collective learning. By sharing ideas, discussing and reflecting together the participants often share know-what knowledge about facts, know-why knowledge about principles and laws and know-how knowledge about skills or capability to do something. They, furthermore, show each other who knows what and who knows what to do, and therefore continue developing know-who knowledge about each other. Cooperation, like the one in the group work, results in promotive interaction as individuals encourage and facilitate each other's efforts to learn (Johnsen and Johnsen 1994). I argue that this altogether constitutes an important way to initiate knowledge mobility.

When the participants share common narratives, visions, mind-sets they may build cognitive trust (McAllister 1995). Owing to a joint topic, problem, or question, the group members have some common goals. Such groups seem, according to Lewin (1935), to create interdependence among its members, resulting in the group becoming a 'whole' with an intrinsic tension among the members to reach the goals. This feeling of wholeness and unity creates emotional bonding and relationships (Johnsen and Johnsen 1994). The best context for creating personal connections is small groups (Krogh et al. 2000), hence the group work emerges as an important condition for building relationships. During this group reflection phase, the participants interact over short, intense periods in temporary groups with stable and standardised roles and clearly defined tasks which may develop swift trust. Working in such groups with common goals may, furthermore, develop a feeling of wholeness and unity that creates emotional bonding. The collective reflection phase, therefore, results in collective learning, know-what-, know-why-, know-how-, and know-who knowledge, cognitive and swift trust, emotional bonding and initiation of knowledge mobility.

During the plenary reflection phase the groups give short presentations, for instance $2 \mathrm{~min}$, of their answers to the given topic, problem, or question. These presentations were often followed up by a plenary discussion and decision, thereby giving the participants a joint direction. The collective reflection phase may therefore result in some know-what-, know-why-, know-how-, and know-who knowledge, trust, and knowledge mobility. 
This discussion of how each phase of Network IGP may influence the findings is summarised in Table 3.

When the network started in 2007, most of the participants were strangers. Many of them were also competitors. To build network relationships with a sufficient level of trust for knowledge sharing and initiating mobility of tacit knowledge in such a context is a huge challenge. It is not sufficient that people meet in the same room, intervention methods to connect them and let them work together in optimal settings for these challenges are crucial. As shown in Table 3, Network IGP was used systematically at most network and team meetings during the emergence stage from 2007 to 2008. Most of the findings reported about the development of network relationships with a sufficient level of trust, and initiating mobility of tacit knowledge, are from the early growth stage from 2008 to 2009. This indicates that Network IGP has played a crucial role to build network relationships with a sufficient level of trust for knowledge sharing and to initiate the mobility of tacit knowledge at these important emergence and growth stages of the network development. One participant also acknowledges the Network IGP as important by claiming: The network is dependent on organizational development techniques, like the ones you use (CEO, System Developer, 2008). Network IGP also seems to be an appropriate

Table 3 The processes and outcome of the phases of Network IGP

\begin{tabular}{|c|c|c|}
\hline Phase & Processes & Outcome \\
\hline \multirow[t]{3}{*}{ Preparing process } & Face-to face communication & Know-who knowledge \\
\hline & Sharing personal knowledge & Word-of-mouth trust \\
\hline & Low-risk and non-work process & \\
\hline \multirow[t]{2}{*}{$\begin{array}{l}\text { Individual } \\
\text { reflection }\end{array}$} & Reflection-on-action & $\begin{array}{l}\text { Externalising tacit } \\
\text { knowledge }\end{array}$ \\
\hline & Individual learning circle & Individual learning \\
\hline \multirow[t]{10}{*}{ Group reflection } & Collective learning circle & $\begin{array}{l}\text { Externalising tacit } \\
\text { knowledge }\end{array}$ \\
\hline & Sharing of know-what, know-why, and know-how & Collective learning \\
\hline & knowledge & Know-what knowledge \\
\hline & Collaborative communication & Know-why knowledge \\
\hline & Storytelling & Know-who knowledge \\
\hline & Promotive interaction & Know-how knowledge \\
\hline & Temporary groups with time pressure & Cognitive trust \\
\hline & Group work with common goal & Swift trust \\
\hline & & Emotional bonding \\
\hline & & Knowledge mobility \\
\hline \multirow[t]{6}{*}{ Plenary reflection } & Sharing of know-what, know-why and & Know-what knowledge \\
\hline & know-how knowledge & Know-why knowledge \\
\hline & & Know-who knowledge \\
\hline & & Know-how knowledge \\
\hline & Direction & Trust \\
\hline & Plenary discussions and prioritising & Knowledge mobility \\
\hline
\end{tabular}


method for the groupwork part of the strategy process in 2010-2011. The later and remaining parts of the network development are due to many reasons. I argue, however, that the foundation of trusting relationships, know-who competence and shared knowledge about each other's practice and equipment, developed during the emergence and growth stages, still plays an important role as a valuable network asset during the networks' sustaining stage.

As the role of facilitator entails the assertion of some kind of force, one important condition for developing a network in this way is the empowerment of the facilitators, in this case the researchers. By developing the network and facilitating several meetings, the researchers used their given power as facilitators to get the participants to work in a certain way. The word 'force' is already mentioned three times by the participants. In addition, another participant stated: It is as if our teacher was sitting there telling us how to act, and we obey, and it does actually work. Yes, I think it is very positive (Middle Manager, System Developer, 2008). One participant shows a slight skepticism to the structure by pointing out: The management can also be a bit too invasive, but I will not argue that this is the case here (CEO, System Developer, 2009). In conclusion, using the power inherent to the role of facilitators to get the participants to use Network IGP seems to be a way of taking the lead which the participants accept and acknowledge.

The challenge in this context was to find a method to build relationships, trust, and initiate knowledge mobility among mostly strangers in an engineering-dominated culture, in a short and efficient way, to improve the firms' innovative capacity. I argue that Network IGP, with processes lasting about $60 \mathrm{~min}$, succeeded in doing this in a remarkably short and efficient way. The main difference between network IGP and dialog conferences is that the former is a more flexible, faster method with a more pronounced time structure. A method with a strong structure seemed to suit the engineering context well, as one of the participants confirmed: You manage the meetings in a structured way (...) I am very much an engineer, and I like structure and two underscores answers, so for me this works very well (Middle Manager, System Developer, 2008).

Of course, the study has some limitations. Other plausible alternative explanations than Network IGP may also have influenced the results. One can argue that simply by bringing the groups together with a common purpose there would be a desire and an impetus to successfully cooperate. I argue, however, that intervention methods to connect them are crucial. Moreover, the reason why the results were achieved in this particular case may also be due to contingent features, e.g. the industry, the situation in NWC, the participants' personality and the influence by the researchers and the network manager. As the findings and discussion show, the use of the Network IGP method appears to have made a significant and well-documented difference in this case. Nevertheless, it would be valuable to utilise the method in a different setting. Although Network IGP is not yet a fully developed concept, further conceptualising is both necessary and auspicable in the future.

\section{Concluding Remarks}

The research question is 'In what way is Network IGP a method for developing innovative SME networks?' and the research problem is how to support organic 
development of trustful network relationships from the inside, and to initiate knowledge mobility. In this case Network IGP was used systematically, especially during the emergence stage, to develop CWN, a regional innovative SME network within water cleansing technology. At the network level, it was used intensively the first 6 months, and then only once until the strategy process $21 / 2$ years later. At the team level, Network IGP was used intensively to start up two of the teams, but not for the third one. The two teams that used Network IGP have had a higher continuity than the third one, but this may also be due to a lot of other factors. At the board level, Network IGP has only been used once, on request at the merger meeting. The findings and discussion indicate that Network IGP has a potential to develop trustful network relationships and to initiate mobility of tacit knowledge, especially during the emergence stage. The use of Network IGP entails a relatively strong process management, which in this case was recruited from the outside. The Network IGP process was mainly employed to let the SMEs themselves develop and agree to the network's vision, aims, strategy, activity plans, and priorities. It is therefore a process that enables an inside-out development, which seems to be an important factor for the achievement of organic growth and internal legitimacy in networks (Human and Provan 2000). Moreover, it appears that Network IGP constitutes a relationships-building method that can be facilitated from the outside in utilising the participant's historical knowledge, and in building the network from the inside. Such organic growth, internal legitimacy-building, and building of networks from the inside are important factors for the lasting and innovative success of networks (Human and Provan 2000). The answer to the research question is therefore that Network IGP is a method that can be facilitated from the outside to build trustful relationships and to initiate mobility of tacit knowledge, especially during the emergence stage of innovative SME networks.

This paper has theoretical, methodological, and practical implications. The theoretical contributions are the outline of activities and processes resulting in building trustful relationships and initiating mobility of tacit knowledge in SME networks. This paper, moreover, contributes with the development and conceptualisation of the hybrid dialog method Network IGP. It also demonstrates that it is possible to support the emergence and development of SME networks from the outside, building on the participants' knowledge and history. Furthermore, this paper contributes methodologically by implementing a longitudinal, qualitative, and process- and outcome-oriented research on networks, which is auspicated by Hoang and Antoncic (2003). The practical implication is that the Networks IGP method is one way to create regional innovative SME networks. The method itself and its implementation may be useful for SMEs, SME networks and politicians engaged in innovation and SME development. It may also be useful for universities and consultants as a contribution to the creation of innovative SME networks.

Acknowledgements This paper was supported by the Norwegian Research Council's VRI programme. The author is grateful for helpful comments from Bjørn Gustavsen and The Nordic Research Network on Trust within and between Organisations, the anonymous reviewers, and the editor.

Open Access This article is distributed under the terms of the Creative Commons Attribution License which permits any use, distribution, and reproduction in any medium, provided the original author(s) and the source are credited. 


\section{References}

Abrams, L. C., Cross, R., Lesser, E., \& Levin, D. Z. (2003). Nurturing interpersonal trust in knowledgesharing networks. Academy of Management Executive, 17(4), 64-77.

Blau, P. M. (1986). Exchange and power in social life. New Brunswick: Transaction Publisher.

Das, T. K., \& Teng, B. S. (1998). Between trust and control: developing confidence in partner cooperation in alliances. Academy of Management Review, 23(3), 491-512.

Dellarocas, C. (2003). The digitization of word of mouth: promise and challenges of online feedback mechanisms. Management Science, 49(10), 1407-1424.

Dhanaraj, C., \& Pharkhe, A. (2006). Orchestrating innovation networks. Academy of Management Review, 31(3), 659-669.

Eisenhardt, K. M. (1989). Building theories from case-study research. Academy of Management Review, 14(4), 532-550.

Emery, F. E., \& Emery, M. (1974). Participative design. Canberra: Centre for Continuing Education, ANU.

Emery, M. (1999). Searching. The theory and practice of making cultural change (Vol. 4). Amsterdam. The Netherlands: John Benjamins Publishing Co.

Ennals, J. R., \& Gustavsen, B. (1999). Work organization and Europe as a development coalition. Amsterdam Philadelphia, Penn: John Benjamin.

Gassmann, O., Enkel, E., \& Chesbrough, H. (2010). The future of open innovation. R\&D Management, $40(3), 213-221$.

Gausdal, A. H. (2008). Developing regional communities of practice by network reflection: the case of the Norwegian electronics industry. Entrepreneurship and Regional Development, 20(3), 209-235.

Gausdal, A. H. (2012). Trust-building processes in the context of networks. Journal of Trust Research, 2(1), 7-30.

Gausdal, A. H., \& Hildrum, J. (2012). Facilitating trust building in networks: a study from the water technology industry. Systemic Practice and Action Research, 25(1), 15-38.

Granovetter, M. S. (1973). The strength of weak ties. American Journal of Sociology, 6, 1360-1380.

Gray, D. E. (2007). Facilitating management learning. Developing critical reflection trough reflective tools. Management Learning, 38(5), 495-517.

Greenwood, D. J., \& Levin, M. (1998). Introduction to action research. Thousand Oaks, CA: Sage.

Gustavsen, B. (1992). Dialogue and developmentcp Maastricht, The Netherlands: Van Gorcum.

Hansen, M. T. (1999). The search-transfer problem: the role of weak ties in sharing knowledge across organization subunits. Administrative Science Quarterly, 44(1), 82-111.

Hoang, H., \& Antoncic, B. (2003). Network-based research in entrepreneurship - a critical review. Journal of Business Venturing, 18(2), 165-187.

Human, S. E., \& Provan, K. G. (2000). Legitimacy building in the evolution of small-firm multilateral networks: a comparative study of success and demise. Administrative Science Quarterly, 45(2), 327365 .

Jensen, M. B., Johnson, B., Lorenz, E. H., \& Lundvall, B. Å. (2007). Forms of knowledge and modes of innovation. Research Policy, 36(2007), 680-693.

Johnsen, D. W., \& Johnsen, R. T. (1994). Learning together and alone. Cooperative, competitive, and individualistic learning (4th ed.). Massachutes: Allyn and Bacon.

Kolb, D. A. (1984). Experiential learning: experience as the source of learning and development. Englewood Cliffs, NJ: Prentice-Hall.

Krogh, G. (1998). Care in knowledge creation. California Management Review, 40(3), 133-153.

Krogh, G., Ichijo, K., \& Nonaka, I. (2000). Enabling knowledge creation: how to unlock the mystery of tacit knowledge and release the power of innovation. Oxford, UK: Oxford University Press.

Levin, D. Z., \& Cross, R. (2004). The strength of weak ties you can trust: the mediating role of trust in effective knowledge transfer. Management Science, 50(11), 1477-1490.

Lewin, K. (1935). A dynamic theory of personality. New York: McGraw-Hill.

Lundvall, B. Å., \& Johnson, B. (1994). The learning economy. Journal of Industry Studies, 1(2), $23-42$.

McAllister, D. J. (1995). Affect- and cognition-based trust as foundation for interpersonal cooperation in organizations. Academy of Management Journal, 38(1), 24-59.

Menzel, M.-P., \& Fornahl, D. (2009). Cluster life cycles-dimensions and rationales of cluster evolution. [Article]. Industrial and Corporate Change, 19(1), 205-238. doi:10.1093/icc/dtp036.

Meyerson, D., Weick, K. E., \& Kramer, R. M. (1996). Swift Trust and Temporary Groups. In R. M. Kramer \& T. R. Tyler (Eds.), Trust in organizations: frontiers of theory and research (pp. 166-195). Thousand Oaks, CA: Sage. 
Miettinen, R. (2002). National innovation system: scientific concept or political rhetoric. Helsinki: Edita.

Mintzberg, H. (2004). Managers not MBAs : a hard look at the soft practice of managing and management development. London: Financial Times Prentice Hall.

Möllering, G. (2006). Trust: reason, routine, reflexitivity. Oxford, UK.: Elsevier.

Nonaka, I. (1994). A dynamic theory of organizational knowledge creation. Organization Science, 5(1), 14-37.

Nonaka, I., \& Takeuchi, H. (1995). The knowledge-creating company: how Japanese companies create the dynamics of innovation. New York: Oxford University Press.

Nooteboom, B. (2002). Trust. Forms, foundations, functions, failures and figures. Cheltenham: Edward Elgar.

Pettigrew, A. M. (1990). Longitudinal field research on change: theory and practice. Organization Science, 1(3), 267-292.

Pittaway, L., Robertson, M., Munir, K., Denyer, D., \& Neely, A. (2004). Networking and innovation: a systematic review of the evidence. International Journal of Management Reviews, 5-6(3-4), 137-168.

Polanyi, M. (1966). The tacit dimension (Reprinted in 1983). London: Routledge \& Kegan Paul.

Porter, M. E. (1990). The competitive advantage of nations. London: Macmillan.

Qvale, T. U. (2008). Regional strategies to meet globalization: how single plants innovate together to remain viable and secure employment. The Greenland Industrial Cluster and Telemark. International Journal of Action Research, 4(1+2), 114-154.

Ramsey, C. (2005). Narrative-from learning in reflection to learning in performance. Management Learning, 36(2), 219-235.

RCN. (2010). Innovation through cooperation (pp. 12). Oslo: Research Council Norway.

Reason, P., \& Bradbury, H. (2001a). Handbook of action research: participative inquiry and practice. London, UK: Sage.

Reason, P., \& Bradbury, H. (2001b). Introduction: Inquiry and Participation in Search of a World Worthy of Human Aspiration. In P. Reason \& H. Bradbury (Eds.), Handbook of action research : Participative inquiry and practice (pp. 1-14). London: Sage.

Reime, M. R. L. (2011). Innovasjon og samarbeid i nettverk. En casestudie i samarbeidsinnovasjon. Master, University of Oslo, Oslo.

Schön, D. A. (1983). The reflective practitioner: how professionals think in action. New York: Basic Books.

Siggelkow, N. (2007). Persuasion with case studies. Academy of Management Journal, 50(1), $20-24$.

Swan, J., Scarbrough, H., \& Robertson, M. (2002). The construction of 'communities of practice' in the management of innovation. Management Learning, 33(4), 477-496.

Wasserman, S., \& Faust, K. (1994). Social network analysis: methods and applications. Cambridge: Cambridge University Press.

Wenger, E. C., McDermott, R., \& Snyder, W. M. (2002). Cultivating communities of practice: a guide to managing knowledge. Boston: Harvard Business School Press.

Whyte, W. F. (1991). Participatory action research. Newbury Park, CA: Sage.

Yin, R. K. (1984). Case study research: design and methods. Beverly Hills, CA: Sage. 